\section{Medicare on the hustings}

A s politicians ramp up their rhetoric in anticipation of a federal election, the great Canadian health care debate is once again being dragged into the scrum of partisan politics. Health care is the issue on which the Liberals are pinning their hopes, and they are anxious, as Mr. Pettigrew now knows, to deliver the message that they are the loyal champions of public health care. The $\$ 120$ billion enterprise that is medicare will be reduced to 10second soundbites on waiting times (too long), drugs (too expensive), emergency departments (too crowded), physicians (can't find one), nurses (too few), home care (you've got to be kidding), and so on. Words like efficiency and innovation will frame the talk of ways and means to renew the health care system, but the debate will splinter, as usual, along party lines into familiar themes: national pharmacare and drug price controls, increased medical school enrolment and more MRI machines, user fees and medical savings accounts, consensus on medically necessary services and revision of the Canada Health Act.

Underlying all of the above is a collective anxiety about the sustainability of public health care and the belief that health care spending is spinning out of control. As far as we can see, our per capita spending is not much different from that in similar systems in other wealthy nations. Leaving the US aside, the top 8 countries (including Canada) spend between $8 \%$ and $10 \%$ of GDP on health care.

But who would fight an election on the platform that there is not much wrong with our health care system and that all we need to do is to continue the commitment to universal health insurance at about current funding levels? So it is that worries about sustainability run in parallel with plans for expansion. From the Liberals, we can expect promises not only of more money, but of money for the new programs proposed in the Romanow report: ${ }^{1}$ pharmacare, expanded home and primary care, targeted technology to reduce waiting times, information technologies, and so on. And with these grand schemes will come renewed debate about the federal role. How much control should Ottawa have over how health transfer payments are spent? For Lawrie McFarlane (see page 1661), a shift in the federal government's function from "submissive purchaser of health services to central overseer of health care delivery ... [would be] a colossal gamble" and would surely be contested in the courts by several of the provinces. ${ }^{2}$

It seems to us that what has been accomplished since the days when Paul Martin, as Finance Minister, slashed health care budgets in a desperate move to control crippling federal deficits, has been a period of relatively stable funding for health care and gradual growth. The proportion of GDP devoted to health care has not changed much over 10 years, while per capita annual spending in constant dollars has grown substantially.

Few patients and health care providers who have lived through deep cuts to health care funding will disagree with Mr. Martin now when he emphasizes the need for "longterm guarantees of predictable, reliable funding." In our view, Canadians should welcome such a pledge from federal politicians to remain steady on health care funding, to the tune of the minimum $25 \%$ of provincial/territorial costs recommended by Romanow. But for the federal government to take an expanded role in health care direction and delivery will remain problematic for many years to come, even aside from the problem of constitutional legitimacy. Between the provinces are undeniable differences of history, experience, ideology and need. The role of the federal government, beyond leadership and responsibility in national public health protection, will have to be limited to ongoing monitoring of public health care and to ensuring that provincial governments maintain the underlying values of national health insurance: universality, comprehensiveness and portability. But whatever federal government emerges from the next election will likely have little choice but to leave decisions on management and allocation to the provinces - if for no other reason than to reduce the intergovernmental conflict that, time and again, has proven to be an impediment to reform. - CMAF

\section{References}

1. Romanow RJ. Building on values: the future of health care in Canada. Saskatoon: Commission on the Future of Health Care in Canada; 2002. Available: www.healthcarecommission.ca (accessed 2004 Apr 16).

2. McFarlane L. Is a perfect storm brewing on the health care front? CMAf 2004;170(11):1661-2. 